\title{
Electronic cigarettes: a survey of users
}

\author{
Jean-François Etter
}

\begin{abstract}
Background: Little is known about users of electronic cigarettes, or their opinions, satisfaction or how and why they use such products.

Methods: An internet survey of 81 ever-users of ecigarettes in 2009. Participants answered open-ended questions on use of, and opinions about, ecigarettes.

Results: Respondents (73 current and 8 former users) lived in France, Canada, Belgium or Switzerland. Most respondents (77\%) were men; $63 \%$ were former smokers and $37 \%$ were current smokers. They had used e-cigarettes for 100 days (median) and drew 175 puffs per day (median). Participants used the ecigarette either to quit smoking (53 comments), to reduce their cigarette consumption (14 comments), in order not to disturb other people with smoke (20 comments), or in smoke-free places (21 comments). Positive effects reported with ecigarettes included their usefulness to quit smoking, and the benefits of abstinence from smoking (less coughing, improved breathing, better physical fitness). Respondents also enjoyed the flavour of ecigarettes and the sensation of inhalation. Side effects included dryness of the mouth and throat. Respondents complained about the frequent technical failures of ecigarettes and had some concerns about the possible toxicity of the devices and about their future legal status.

Conclusions: Ecigarettes were used mainly to quit smoking, and may be helpful for this purpose, but several respondents were concerned about potential toxicity. There are very few published studies on ecigarettes and research is urgently required, particularly on the efficacy and toxicity of these devices.
\end{abstract}

\section{Background}

In recent years several manufacturers, mainly in China, have produced electronic cigarettes (ecigarettes) that are distributed in western countries, often by small, newly established companies [1-4]. Electronic cigarettes look and feel like cigarettes, but do not burn tobacco. The several existing brands vary but, in general, ecigarettes contain a battery and an electronic device that produces a warm vapour or 'mist'. The vapour usually contains nicotine and often - but not always - contains propylene glycol [5]. The vapour is inhaled and, as the user exhales, some visible vapour is released, but no tobacco smoke. Some ecigarettes also contain a light-emitting diode in the tip that glows when the user puffs, to resemble the burning end of a cigarette. The nicotine content of the cartridge varies, and the cartridges usually contain chemical additives and flavours (such as various brands of tobacco, chocolate, coffee, mint or fruit). The cartridges can usu-

\footnotetext{
* Correspondence: Jean-Francois.Etter@unige.ch

1 Institute of Social and Preventive Medicine, Faculty of Medicine, University of Geneva, Switzerland

Full list of author information is available at the end of the article
}

ally be refilled, and refill bottles are provided with the device.

Electronic cigarettes are probably less harmful than tobacco smoking, but they are almost certainly more dangerous than medicinal nicotine inhalers [6,7]. However, to our knowledge, there is no published data on the safety of ecigarettes. Internationally, the legality of ecigarettes varies; they cannot be sold in Australia, Brazil, Canada, Denmark or Switzerland, but their sale is authorized in other countries (e.g. China, New Zealand) [5,8,9]. Analyses conducted by the United States Food and Drug Administration (FDA) showed that ecigarettes contain carcinogens, including nitrosamines, toxic chemicals such as diethylene glycol, and tobacco-specific components suspected of being harmful to humans (anabasine, myosmine, and beta-nicotyrine) [6]. The FDA also found that ecigarette cartridges labelled as containing no nicotine did in fact contain low levels of nicotine. Some manufacturers do not disclose the ingredients in their products. Furthermore, ecigarettes are not manufactured according to the high standards imposed on pharmaceutical companies. Consequently, the inhaled vapour may contain 
impurities that may be dangerous to consumers [6]. In particular, the origin of the nicotine itself is uncertain, as pesticide-grade nicotine rather than pharmacologicalgrade nicotine may be used in ecigarettes.

Little is known about ecigarettes, as few research reports have been published $[10,11]$. In addition to the FDA report mentioned above, reports from New Zealand, funded by Ruyan (a Chinese manufacturer of ecigarettes) concluded that the mist from the Ruyan ecigarette contains acetaldehyde and mercury [12,13]. A randomised trial in 40 smokers found that the Ruyan ecigarette delivered nicotine to the blood more rapidly than the nicotine inhaler, but less rapidly than cigarettes, and that the effect of the ecigarette on craving was similar to that of the nicotine inhaler, but less than that of cigarettes [14]. A recent U.S. study found that 10 puffs of an ecigarette delivered little or no nicotine [15].

The mist from ecigarettes is inhaled into the lung [13]. Although the particle size is apparently too small to ensure deposition in the lung alveoli [12], we are not aware of any study of lung absorption of ecigarette mist. Because lung inhalation may enable nicotine to pass rapidly into the blood, and thus rapidly relieve craving and tobacco withdrawal symptoms [14], ecigarettes have the potential to be at least as effective as currently approved nicotine replacement therapy (NRT) products, none of which deliver nicotine to the lung. In addition, the similarities in shape, actions and inhalation between ecigarettes and tobacco cigarettes could also help smokers quit. However, as there are no data to support the manufacturers' claims that ecigarettes help smokers quit, the World Health Organization asked the companies not to make any therapeutic claims $[7,16]$. If they claimed that ecigarettes help smokers quit, manufacturers would be subject to the legislation and regulation that applies to NRT products. In order to avoid this, some ecigarettes are now marketed for enjoyment, or as devices that enable smokers to "smoke" everywhere, including smokefree places [3,4]. Nonetheless, some distributors present their products as an alternative to tobacco smoking, more or less implicitly suggesting that ecigarettes can be used to aid smoking cessation $[1,2]$.

One may hypothesize that the positive effects of ecigarettes may include smoking cessation, smoking reduction or relapse prevention. The ecigarette could also be used as an aid during a preparation period before cessation, similar to the pre-cessation treatment or "cut down to quit" approach that is an approved indication for NRT [17]. On the other hand, ecigarettes may be dangerous because of the frequent and longterm lung inhalation of diethylene glycol, nicotine and other toxic components, and because of the sub-standard manufacturing process, relative to pharmaceutical products [7]. Because of its rapid nicotine delivery [14], the ecigarette also has the potential to be addictive. In addition, the refill bottles may be dangerous as they contain up to one gram of nicotine, whereas the fatal dose of nicotine is estimated to be 30 to $60 \mathrm{mg}$ for adults and $10 \mathrm{mg}$ for children [5]. The ecigarette may also enable smokers to continue to 'smoke' in smoke-free environments, thus delaying or preventing cessation in people who might otherwise quit. Finally, the fruit and chocolate flavours may appeal to young people, and this raises the concern that ecigarettes may facilitate initiation of nicotine dependence in young never-smokers [5]. However, none of these hypotheses has yet been tested.

Because of the huge burden of tobacco-related death and disease, and because ecigarettes have potential to help smokers quit, there is an urgent need for research into these products. First, there is a need to know why and how these products are used, and whether users are satisfied with them. The aim of this study was to assess usage patterns of ecigarettes, reasons for use, and users' opinions of these products.

\section{Methods}

As ecigarettes are mainly sold online, the internet is a logical way to reach users. We therefore posted a survey form, in French, on the smoking cessation website StopTabac.ch over a 34 day period between September and October 2009. This website receives approximately 120,000 visitors per month and is principally visited either by smokers who intend to quit or by recent quitters $[18,19]$. Links to the survey were posted on websites that either provide information about ecigarettes (ecigmag.com, forumecigarette.com) or sell them (econoclope.com, sedansa.be). After discussion with the head of the ethics committee of the Geneva University Hospitals (community medicine section, the committee to which our Institute is submitted), the study was exempted from approval.

Eligible participants were people who declared that they had ever used an ecigarette and who provided the brand name of the ecigarette that they had used most often. Subjects who did not name a brand were excluded, because this raised doubts about whether they had actually used an ecigarette. On the survey form, participants indicated whether they had ever used ecigarettes or were currently using them (subdivided into daily user, nondaily user, former user, never used). They also provided the total number of days that they had been using ecigarettes, the brand they used most often, the nicotine dose per unit, the flavour and the cost per package (using open-ended questions). In addition, subjects indicated whether ecigarettes had helped them to quit smoking, and current users indicated the number of puffs per day on ecigarettes. 
In response to open-ended questions, participants wrote where they bought their ecigarettes, the reasons why they used them, what they considered to be the beneficial and undesirable effects of ecigarettes, and the most positive and negative points about the product. If they had stopped using ecigarettes, they explained why. Participants also listed which questions they had asked themselves about ecigarettes, and gave their opinion on the information leaflets or documents inserted in the ecigarette packages. Finally, they wrote general comments on the ecigarette.

Other questions also covered smoking status (daily, non-daily, former smoker, never smoker). Smokers stated the number of cigarettes they smoked per day, and former smokers stated when they had quit smoking. Participants were asked to supply their age, sex and country of residence.

Medians rather than means were used for continuous variables because medians are less sensitive to outliers, which can excessively influence means in small sample sizes.

\section{Results}

Answers were obtained from 214 people, but 123 of these had never used ecigarettes and ten did not name the brand of their ecigarette. These 133 subjects were excluded. All subsequent analyses included only the 81 respondents who declared that they had ever used ecigarettes and who indicated the brand that they had used most often. These 81 respondents included 72 daily users of ecigarettes, one non-daily user and eight former users (Table 1). They were relatively young (median age 37 years), and most (77\%) were men. Respondents lived in France (81\%), Belgium (8\%), Canada (6\%) and Switzerland (5\%). Most (63\%) were former smokers who had quit smoking relatively recently (median duration of abstinence: 100 days) (Table 1$)$.

\section{Use of the electronic cigarette}

Most respondents had been using the ecigarette for slightly longer than three months, and current users took 175 puffs per day (median) from their device (Table 1). Sixteen different brands of ecigarettes were named, the most frequent being Janty $(n=17)$, Joye $(n=17)$, Sedansa $(\mathrm{n}=14)$, Econoclope $(\mathrm{n}=9)$, Liberty-cig $(\mathrm{n}=8)$, Smoke51 and Edsylver $(\mathrm{n}=2$ each). All these brands of ecigarette deliver nicotine, and the median dose of nicotine per unit was $14 \mathrm{mg}$. The preferred flavour (open-ended field, 78 answers) was tobacco ( $\mathrm{n}=46$, various flavours, e.g. "Turkish blend", "K-mel"), followed by mint $(n=6)$, fruit $(n=5$, e.g. "apple"), vanilla $(\mathrm{n}=4)$, coffee $(\mathrm{n}=3)$ and tea $(\mathrm{n}=2)$. Twelve respondents used several of these flavours.

Most respondents ( $\mathrm{n}=74 ; 94 \%$ of 79 answers) had bought their ecigarette on the internet, two had bought
Table 1: Characteristics of ecigarette users, and usage patterns

\begin{tabular}{|c|c|}
\hline Characteristic & \\
\hline Number of respondents & 81 \\
\hline Age, median (range), years & $37(19-65)$ \\
\hline Men (\%) & 77 \\
\hline \multicolumn{2}{|l|}{ Smoking status (\%) } \\
\hline Former smokers & 63 \\
\hline Daily smokers & 23 \\
\hline $\begin{array}{l}\text { Occasional (non-daily) } \\
\text { smokers }\end{array}$ & 13 \\
\hline $\begin{array}{l}\text { Cigarettes per day, in } \\
\text { smokers (median) }\end{array}$ & 12 \\
\hline $\begin{array}{l}\text { Days of abstinence, in former } \\
\text { smokers, median ( } 25^{\text {th }} \text { and } \\
75^{\text {th }} \text { percentiles) }\end{array}$ & $100(30,210)$ \\
\hline \multicolumn{2}{|l|}{ Use of electronic cigarettes } \\
\hline $\begin{array}{l}\text { Days of use of the e-cigarette, } \\
\text { median }\left(25^{\text {th }} \text { and } 75^{\text {th }}\right. \\
\text { percentiles })\end{array}$ & $100(30,210)$ \\
\hline $\begin{array}{l}\text { Number of puffs per day, } \\
\text { median ( } 25^{\text {th }} \text { and } 75^{\text {th }} \\
\text { percentiles) }\end{array}$ & $175(90,275)$ \\
\hline $\begin{array}{l}\text { Number of puffs per day, } \\
\text { range }\end{array}$ & 10 to 600 \\
\hline $\begin{array}{l}\text { Price per package, median, } \\
\text { Euros (U.S. dollars) }\end{array}$ & $40(60)$ \\
\hline $\begin{array}{l}\text { Median dose of nicotine per } \\
\text { unit, } \mathrm{mg}\left(25^{\text {th }} \text { and } 75^{\text {th }}\right. \\
\text { percentiles })\end{array}$ & $14(10,16)$ \\
\hline \multicolumn{2}{|l|}{$\begin{array}{l}\text { Does (did) the e-cigarette } \\
\text { help you quit smoking? (\%) }\end{array}$} \\
\hline Yes, a lot & 79 \\
\hline Yes, somewhat & 16 \\
\hline No, not at all & 5 \\
\hline
\end{tabular}

their device in China, two at a tobacco retail shop and one had bought it second hand. When asked whether the ecigarette helped them quit smoking, most respondents (79\%) answered "a lot" (Table 1).

When asked why they chose to use ecigarettes (three open-ended fields, 225 comments), the most frequent answers were: that they used it to quit smoking; for their health (as ecigarettes were perceived to be less toxic than tobacco, e.g.: "it is better for health than tobacco"); because ecigarettes are less expensive than regular cigarettes; because ecigarettes can be smoked everywhere, including smoke-free places (e.g.: "I don't need to go outside to smoke anymore"); to avoid disturbing other people with second-hand smoke; for the pleasure of smoking it 
(e.g.: "to continue to inhale, which is something I like"), and to reduce their cigarette consumption (Table 2).

The most frequently cited beneficial effects of ecigarettes (two open-ended fields, 134 comments) were: that it improved breathing and respiration (e.g.: "I have less breathlessness on exertion"); that it helps to quit smoking (e.g.: "I have quit smoking without problems"); that respondents coughed less, expectorated less and had fewer sore throats; that it improved their health and physical fitness; and that it did not cause unpleasant odours or bad breath (Table 3). Interestingly, one respondent suggested that the ecigarette device might be useful to administer other medications to the bronchia or lung. The two open-ended fields on the undesirable effects of ecigarettes elicited 61 comments (only half the number of comments received on the beneficial effects). The most frequent responses were that ecigarettes caused dry mouth and throat, vertigo, headache or nausea (Table 3).

The most frequently cited positive features of ecigarettes (three open-ended fields, 208 comments) were: that respondents liked the taste and variety of flavours;

Table 2: Reasons for using e-cigarettes: open-ended comments from e-cigarette users

\begin{tabular}{|c|c|}
\hline & Number of comments \\
\hline To quit smoking & 53 \\
\hline $\begin{array}{l}\text { For health, as e-cigarettes } \\
\text { were perceived to be less } \\
\text { toxic than tobacco }\end{array}$ & 49 \\
\hline $\begin{array}{l}\text { Less expensive than regular } \\
\text { cigarettes }\end{array}$ & 26 \\
\hline $\begin{array}{l}\text { Can be smoked everywhere, } \\
\text { including smoke-free places }\end{array}$ & 21 \\
\hline $\begin{array}{l}\text { To avoid disturbing other } \\
\text { people, or producing } \\
\text { environmental tobacco } \\
\text { smoke or the smell of stale } \\
\text { smoke }\end{array}$ & 20 \\
\hline $\begin{array}{l}\text { For the pleasure of smoking, } \\
\text { including the pleasure of } \\
\text { inhaling and smoking- } \\
\text { related actions }\end{array}$ & 19 \\
\hline $\begin{array}{l}\text { To reduce cigarette } \\
\text { consumption }\end{array}$ & 14 \\
\hline Curious to test a new product & 10 \\
\hline $\begin{array}{l}\text { Ecigarettes taste and smell } \\
\text { good }\end{array}$ & 8 \\
\hline $\begin{array}{l}\text { Previously failed to quit with } \\
\text { either nicotine patch or } \\
\text { bupropion }\end{array}$ & 3 \\
\hline To get nicotine & 2 \\
\hline $\begin{array}{l}\text { Total (from three open-ended } \\
\text { fields) }\end{array}$ & 225 \\
\hline
\end{tabular}

Table 3: Beneficial and undesirable effects of e-cigarettes: open-ended comments from ecigarette users

\begin{tabular}{|c|c|}
\hline & Number of comments \\
\hline $\begin{array}{l}\text { Beneficial effects (total from } \\
\text { two open-ended fields) }\end{array}$ & 134 \\
\hline $\begin{array}{l}\text { Improves breathing and } \\
\text { respiration }\end{array}$ & 31 \\
\hline $\begin{array}{l}\text { Less cough, less } \\
\text { expectoration, fewer sore } \\
\text { throats }\end{array}$ & 23 \\
\hline Helps to quit smoking & 20 \\
\hline $\begin{array}{l}\text { Improves health and physical } \\
\text { fitness }\end{array}$ & 17 \\
\hline $\begin{array}{l}\text { Improves sense of taste and } \\
\text { smell }\end{array}$ & 11 \\
\hline $\begin{array}{l}\text { Does not cause unpleasant } \\
\text { odours or bad breath }\end{array}$ & 10 \\
\hline $\begin{array}{l}\text { Helps to reduce cigarette } \\
\text { consumption }\end{array}$ & 7 \\
\hline Sleeps better & 4 \\
\hline Less craving for cigarettes & 4 \\
\hline Cost & 4 \\
\hline $\begin{array}{l}\text { Pleasure of smoking the e- } \\
\text { cigarette }\end{array}$ & 2 \\
\hline $\begin{array}{l}\text { Useful device to administer } \\
\text { other medications to the } \\
\text { bronchia or lung }\end{array}$ & 1 \\
\hline $\begin{array}{l}\text { Undesirable effects (total from } \\
\text { two open-ended fields) }\end{array}$ & 61 \\
\hline Dry mouth and throat & 16 \\
\hline Vertigo, headache or nausea & 7 \\
\hline Bad taste & 4 \\
\hline Weight gain & 3 \\
\hline $\begin{array}{l}\text { Technical problems } \\
\text { (batteries) }\end{array}$ & 3 \\
\hline $\begin{array}{l}\text { Difficult to accurately control } \\
\text { dose of nicotine }\end{array}$ & 3 \\
\hline Cost & 3 \\
\hline No undesirable effects & 13 \\
\hline Miscellaneous comments & 9 \\
\hline
\end{tabular}

they appreciated the beneficial effects of the ecigarette on their health, breathing and cough; the absence of unpleasant odours or bad breath; they appreciated the pleasure of inhalation, and harsh sensation in the throat; they liked the act of using the ecigarette, which is similar to smoking; the ecigarette is less toxic than tobacco smoke; it facilitates smoking cessation; and that it can be used everywhere (Table 4 ). 
When asked about the three most negative aspects of ecigarettes (three fields, 154 comments), respondents complained in particular about the poor quality of the devices. They also reported that that ecigarettes were difficult or impractical to use (e.g. "it is difficult to refill the liquid"), that the dosage was difficult to adjust (either too high or too low), that the liquid can leak out during use, and complained about the lack of information on the composition of the vapour and any health risks associated with ecigarettes (Table 4).

Respondents also stated which questions they had asked themselves about ecigarettes (three fields, 112 comments). This section showed that users wondered whether ecigarettes were safe, what the effects on health were, and whether ecigarettes are toxic (59 comments, including five that specifically mentioned propylene glycol). Respondents were also concerned that the e-cigarette might be banned, and about its future legal status (19 comments, e.g.: "let's hope it will not be prohibited"). They wanted to know about the composition of the liquid in the cartridge $(10$ comments, e.g.: "What exactly is the content of this liquid?", including four comments on the quality of the liquids), why no serious studies on ecigarettes have been published ( 5 comments), why ecigarettes are not sold in pharmacies (4 comments) and why the devices are not produced in western countries (3 comments).

When asked to comment on the documentation that accompanied their ecigarette (one field, 70 comments), most respondents answered that the inserts were good or satisfactory (31 comments), seven responded that they were only adequate, 15 responded that they contained too little information, four reported that there was no explanatory leaflet with their ecigarette, and two complained that there was no explanation of the health effects of ecigarettes. Three people responded that they used the internet and online discussion forums to obtain more information on ecigarettes (e.g.: "the insert was very brief, but fortunately, there are specialized internet discussion forums").

The section that asked participants to write general comments on the ecigarette (one field) elicited 64 comments. Twenty-one comments were very positive or enthusiastic (e.g. "brilliant" (6 times), "miracle product", "unbelievable", "very satisfied"), and 11 were positive but more neutral (e.g.: "good", "I recommend it"). Respondents also considered that the ecigarette helped them quit smoking (14 comments), that it was more effective than either nicotine patch or bupropion (5 comments), and that it enabled them to reduce their cigarette consumption (3 comments). Three people feared that the ecigarette would soon be banned. Four commented that ecigarettes need technical improvement, and six wrote negative comments (e.g.: "not helpful to quit", "avoid it").
Table 4: The most positive and negative aspects of ecigarettes: open-ended comments from e-cigarette users

\begin{tabular}{|c|c|}
\hline & Number of comments \\
\hline $\begin{array}{l}\text { Positive points (total from } \\
\text { three open-ended fields) }\end{array}$ & 208 \\
\hline Taste and variety of flavours & 38 \\
\hline $\begin{array}{l}\text { Beneficial effects on health, } \\
\text { breathing and cough }\end{array}$ & 26 \\
\hline $\begin{array}{l}\text { No unpleasant odours or bad } \\
\text { breath }\end{array}$ & 23 \\
\hline $\begin{array}{l}\text { Inhalation, including harsh } \\
\text { sensation in the throat and } \\
\text { pleasure of inhaling }\end{array}$ & 16 \\
\hline $\begin{array}{l}\text { Less toxic than tobacco } \\
\text { smoke }\end{array}$ & 15 \\
\hline Facilitates smoking cessation & 15 \\
\hline $\begin{array}{l}\text { Can be used everywhere (the } \\
\text { freedom) }\end{array}$ & 15 \\
\hline $\begin{array}{l}\text { The gestures or actions } \\
\text { (similar to smoking) }\end{array}$ & 13 \\
\hline Ease of use, design & 10 \\
\hline $\begin{array}{l}\text { Less expensive than } \\
\text { cigarettes }\end{array}$ & 9 \\
\hline $\begin{array}{l}\text { No environmental tobacco } \\
\text { smoke }\end{array}$ & 8 \\
\hline $\begin{array}{l}\text { Facilitates smoking } \\
\text { reduction }\end{array}$ & 5 \\
\hline $\begin{array}{l}\text { No ash, dirt, or burned } \\
\text { clothes }\end{array}$ & 5 \\
\hline $\begin{array}{l}\text { Can choose the dose of } \\
\text { nicotine and number of puffs }\end{array}$ & 5 \\
\hline Relieves craving for tobacco & 3 \\
\hline $\begin{array}{l}\text { Improves sense of smell and } \\
\text { taste }\end{array}$ & 2 \\
\hline $\begin{array}{l}\text { Negative points (total from } \\
\text { three open-ended fields) }\end{array}$ & 154 \\
\hline $\begin{array}{l}\text { Poor quality, lack of reliability } \\
\text { and frequent failures }\end{array}$ & 40 \\
\hline $\begin{array}{l}\text { Batteries discharge too } \\
\text { rapidly }\end{array}$ & 27 \\
\hline Too expensive & 14 \\
\hline Bad taste & 14 \\
\hline $\begin{array}{l}\text { Difficult or impractical to use; } \\
\text { dosage is difficult to adjust }\end{array}$ & 10 \\
\hline $\begin{array}{l}\text { The liquid may leak during } \\
\text { usage }\end{array}$ & 10 \\
\hline Only sold on the internet & 9 \\
\hline
\end{tabular}




\begin{tabular}{|c|c|}
\hline (Continued) & \\
\hline $\begin{array}{l}\text { No studies or information on } \\
\text { the composition of the } \\
\text { vapour and the health risks of } \\
\text { the e-cigarette }\end{array}$ & 8 \\
\hline $\begin{array}{l}\text { Cartridges do not last long } \\
\text { enough }\end{array}$ & 6 \\
\hline $\begin{array}{l}\text { Difficult to stop using the } \\
\text { ecigarette without relapsing } \\
\text { to smoking }\end{array}$ & 4 \\
\hline Too big or too heavy & 3 \\
\hline $\begin{array}{l}\text { Too often asked by friends or } \\
\text { colleagues to explain the } \\
\text { device }\end{array}$ & 2 \\
\hline Miscellaneous & 7 \\
\hline
\end{tabular}

Eight respondents had stopped using ecigarettes, and were asked to indicate why (two fields, 15 comments). Reasons included: it did not help me quit smoking (6 comments); it did not taste like cigarettes (3 comments); poor quality or not reliable (3 comments); because of concerns about risks and side-effects of ecigarettes (3 comments).

Interestingly, several respondents used a neologism (vapoter, in French) to describe the action of smoking an ecigarette; this term probably originated from "vapour" and spread in online discussion forums. The corresponding terms used on English-language forums (e.g. ecigarette-forum.com) are "vaping" and "vaper".

\section{Discussion}

Although, for legal reasons, ecigarettes are mainly marketed to current smokers either for enjoyment or for use in smoke-free places, our results suggest that most people who buy these products are current and former smokers who use ecigarettes to help quit smoking, just as they would use NRT. Our survey also showed that ecigarettes were liked by users, and were used quite intensively by this sample; almost all respondents were daily ecigarette users, and the number puffs per day (175) was substantial. However, as ecigarettes deliver about one-tenth of the nicotine per puff compared to cigarettes [12], this intensive puffing pattern may result in less exposure to nicotine than smoking. Interestingly, the median duration of ecigarette use corresponded to the median duration of abstinence in former smokers (100 days in both cases).

Respondents reported more positive than negative effects with ecigarettes: many reported positive effects on the respiratory system (breathing better, coughing less), which were probably associated with stopping smoking [20]. The fact that ecigarettes do not produce any unpleasant odours or environmental tobacco smoke was also appreciated. Most importantly, many respondents reported that the ecigarette helped them quit smoking, and several compared it favourably with either nicotine patch or bupropion. These preliminary findings, together with data showing that ecigarettes relieve craving and withdrawal [14], suggest that the ecigarette may be an effective aid to smoking cessation, and therefore merits serious investigation for this purpose. Ideally, future trials should compare the efficacy of ecigarettes versus NRT (particularly the nicotine inhaler), bupropion or varenicline. However, as ecigarettes are probably more toxic than NRT products [6], the former should probably only be recommended to smokers if they are substantially more effective than current NRTs, and if the toxic constituents of ecigarettes can be eliminated.

Interestingly, dry mouth and throat was a frequent adverse effect of the ecigarette. It may be useful to investigate why this occurs and how it might be minimised. It would also be interesting to investigate why ecigarettes appeal more to men than to women. Many respondents complained of the poor quality of ecigarettes, their frequent failures, the lack of durability of cartridges and batteries, and that the liquid sometimes leaks from the device during usage. Apparently competition between manufacturers has not yet resulted in products of sufficient technical quality.

Although users' comments were generally positive, many were concerned about the safety and toxicity of ecigarettes, and questioned why no study has yet investigated these aspects. Several respondents were also concerned about the future legal status of ecigarettes, and that they may possibly be banned. Indeed, health authorities in several countries have published warnings about, or have prohibited the sale of, ecigarettes [5-8]. From a public health perspective, however, the question is whether - at a population level - the potential benefits of the ecigarette outweigh its drawbacks. If ecigarettes are more effective than current NRTs, but are withdrawn from the market until approved as smoking cessation aids, ecigarette users might revert to smoking tobacco, which is more hazardous than ecigarettes. This could have a significant, negative impact on public health, because it can take several years to obtain legal approval for a new drug delivery system.

On the other hand, ecigarettes are not currently manufactured to the same rigorous standards as pharmaceutical products; they currently contain toxic components and are therefore almost certainly less safe than NRT products [6]. The legal status of the e-cigarette is unclear in many countries, and its regulation is complex; it is neither classed as a tobacco product, nor food, nor is it registered as a medicine. From the legal perspective, there is a difficult balance between the need to protect consumers 
and the possibility now being offered to smokers to use a new, acceptable and potentially effective device to stop smoking. Given the enormous burden of disease and death caused by tobacco smoking, there is an urgent need for research into the toxicity, efficacy and public health impact of ecigarettes [10]. In addition, whether devices that resemble ecigarettes could be used to deliver medications other than nicotine to the lung and bronchia also warrants investigation. As the manufacturers and distributors of ecigarettes are relatively small companies that may be unable to afford the research costs, or possess the expertise or manpower to go through the regulatory approval process, support from governments, public health organizations or foundations may be needed to produce evidence on these novel devices.

One limitation of our study is that it was conducted in a self-selected sample of internet users. Whether this method over-sampled satisfied users, long-term users or heavy users of ecigarettes is unknown. Compared to population-based samples of smokers in Europe or the United States, visitors to the Stop-Tabac.ch website are more likely to have made a quit attempt in the previous year, are more motivated to quit smoking, are slightly less dependent on tobacco, and are more highly educated $[18,19]$. Thus, although our results provide useful and interesting preliminary information on ecigarette users, our findings may not be generalizable and should be interpreted with caution.

\section{Conclusions}

Our results suggest that ecigarettes are used mainly to quit smoking, and may be useful for this purpose. However, users were concerned about the potential toxicity of these devices. Very few studies have investigated ecigarettes and research is now urgently required, particularly to establish the efficacy and toxicity of these devices.

\section{Funding}

No external funding

\section{Competing interests}

The Institute of Social and Preventive Medicine of the University of Geneva received trial medications in 2005 from Pfizer, and the author consulted for Pfizer, a manufacturer of smoking cessation medications, in 2006-2007 (on the Swiss varenicline advisory board). No competing interest since then. No link to companies that either produce or distribute ecigarettes.

\section{Acknowledgements}

Vincent Baujard, from the HON Foundation, Geneva, Switzerland http:// www.hon.ch developed the software for data collection.

\section{Author Details}

Institute of Social and Preventive Medicine, Faculty of Medicine, University of Geneva, Switzerland

Received: 27 October 2009 Accepted: 4 May 2010

Published: 4 May 2010

\section{References}

1. Sedansa [http://www.sedansa.be]. Accessed Jan. 14, 2010

2. Joyetech [http://www.joyetech.com]. Accessed Jan. 14, 2010

3. Smoke 51 [http://europe.smoke51.com/]. Accessed Jan. 14, 2010

4. Econo'clope [http://www.econoclope.com]. accessed jan. 14, 2010

5. American-Legacy-Foundation: Electronic cigarette ("e-cigarette") fact sheet. 2009 [http://www.americanlegacy.org/PDFPublications/ ElectronicCigarette FactSheet.pdf. American Legacy Foundation

6. FDA: Summary of Results: Laboratory Analysis of Electronic Cigarettes Conducted By FDA. 2009 [http://www.fda.gov/NewsEvents/ PublicHealthFocus/ucm 173146.htm]. US: Food and Drug Administration (FDA)

7. WHO: WHO Study Group on Tobacco Product regulation. Report on the scientific basis of tobacco product regulation: third report of a WHO study group. In WHO Technical Report Series Volume 955. Geneva: WHO; 2009 .

8. OFSP: Lettre d'information $n^{\circ} 146$ : cigarettes électroniques. Office fédéral de la santé publique Berne; 2009.

9. Laugesen M: Nicotine electronic cigarette sales are permitted under the Smokefree Environments Act. NZMed J 123(1308):103-105.

10. Henningfield JE, Zaatari GS: Electronic nicotine delivery systems: emerging science foundation for policy. Tob Contro/ 19(2):89-90.

11. Flouris $A D$, Oikonomou DN: Electronic cigarettes: miracle or menace? BMJ 2010, 340:c311.

12. Laugesen M: Ruyan e-cigarette bench-top tests. Poster presented at the Conference of the Society for Research on Nicotine and Tobacco Dublin, April 27-30, 20092009.

13. Laugesen M: Safety report on the Ruyan e-cigarette cartridge and inhaled aerosol. Christchurch, New Zealand: Health New Zealand Ltd; 2008

14. Bullen C, McRobbie H, Thornley S, Glover M, Lin R, Laugesen M: Effect of an electronic nicotine delivery device (e cigarette) on desire to smoke and withdrawal, user preferences and nicotine delivery: randomised cross-over trial. Tobacco Control 2010, 19(2):98-103.

15. Eissenberg $T$ : Electronic nicotine delivery devices: ineffective nicotine delivery and craving suppression after acute administration. Tob Control 2010, 19(1):87-88.

16. WHO: Marketers of electronic cigarettes should halt unproved therapy claims. 2008 [http://www.who.int/mediacentre/news/releases/2008/ pr34/en/index.htmll. Geneva, World Health Organization

17. Wang D, Connock M, Barton P, Fry-Smith A, Aveyard P, Moore D: 'Cut down to quit' with nicotine replacement therapies in smoking cessation: a systematic review of effectiveness and economic analysis. Health Technol Assess 2008, 12(2):iii-iv. ix-xi, 1-35

18. Etter JF, Perneger TV: A comparison of cigarette smokers recruited through the Internet or by mail. Int J Epidemiol 2001, 30(3):521-525.

19. Wang J, Etter JF: Administering an effective health intervention for smoking cessation online: the international users of Stop-Tabac. Prev Med 2004, 39(5):962-968.

20. Etter JF: Short-term change in self-reported COPD symptoms after smoking cessation in an Internet sample. Eur Respir J 2009 in press.

Pre-publication history

The pre-publication history for this paper can be accessed here: http://www.biomedcentral.com/1471-2458/10/231/prepub

doi: $10.1186 / 1471-2458-10-231$

Cite this article as: Etter, Electronic cigarettes: a survey of users BMC Public Health 2010, 10:231 